\title{
ANALISIS KEJADIAN SPREAD F IONOSFER PADA GEMPA SOLOK 6 MARET 2007
}

\author{
Dwi Pujiastuti ${ }^{1}$, Sumi Daniati ${ }^{1}$, Badrul Mustafa ${ }^{2}$ Ednof $^{3}{ }^{3}$ \\ ${ }^{1}$ Laboratorium Fisika Bumi Jurusan Fisika Universita Andalas \\ ${ }^{2}$ Jurusan Teknik Sipil Universitas Andalas \\ ${ }^{3}$ Lembaga Penerbangan dan Antariksa Nasional SPD Kototabang \\ Dwi_Pujiastuti@yahoo.com
}

\begin{abstract}
ABSTRAK
Analisis kejadian Spread F menggunakan data ionosonda FMCW di stasiun pengamat dirgantara LAPAN Kototabang telah dilakukan untuk melihat keterkaitan antara kejadian gempa bumi Solok dengan kemunculan Spread F. Dari hasil pengamatan pada tanggal 20 Februari sampai 20 Maret 2007 kemunculan Spread F terjadi pada tanggal 2, 3 dan 5 Maret 2007. Kemunculan Spread F tersebut diprediksi sebagai prekusor gempa bumi Solok yang terjadi pada tanggal 6 Maret 2007 karena pada saat itu aktivitas geomagnet dan matahari dalam kondisi normal. Setelah gempa Solok aktivitas ionosfer kembali menunjukkan kondisi yang normal.
\end{abstract}

Kata kunci : Spread F, ionosonda, ionosfer, prekursor

\section{PENDAHULUAN}

Seiring dengan perkembangan ilmu geofiska telah dilakukan berbagai penelitian untuk untuk melihat bagaimana keterkaitan antara parameter-parameter fisis dengan proses kejadian gempa. Salah satu tantangan dalam ilmu seismologi sekarang adalah memprediksi kapan terjadinya gempa bumi berdasarkan perubahan-perubahan parameter fisis yang ditimbulkan oleh kejadian gempa bumi. Penelitian dalam bidang prediksi gempa memerlukan perhatian yang serius khususnya untuk wilayah Indonesia,yang merupakan daerah rawan gempa bumi. Pengetahuan tentang gempa dan prediksinya diharapkan dapat membantu kesiap-siagaan masyarakat dalam menghadapi bencana.

Beberapa metode yang digunakan untuk memprediksi gempa yaitu seismogeological, statistic analysis of seismicity, corelation analysis dan metode precursor. Dengan berkembangnya ilmu seismologi, teori-teori untuk prediksi gempa bumi semakin banyak bermunculan. Teori-teori tersebut pada umumnya didapatkan dengan melakukan studi kasus terhadap gempa-gempa besar yang pernah terjadi.

Salah satu penelitian mengenai prediksi gempa yang pernah dilakukan adalah dengan mengamati atmosfer bumi. Efek seismik pada ionosfer telah cukup banyak ditelaah oleh ilmuwan dalam dan luar negeri. Telaah tersebut menyatakan ada keterkaitan yang erat antara anomali pada variasi harian ionosfer dengan aktivitas seismik sebelum terjadi gempa kuat $(M>5)$. Aktivitas seismik yang terjadi di kerak bumi melepas gas radioaktif Radon ke udara, dan peluruhan gas ini memicu penambahan ion di lapisan ionosfer (Pulinets dan Boyarchuk, 2004). Selama aktivitas seismik meningkat, juga muncul medan listrik dan gelombang elektromagnetik akibat gesekan antar lempeng. Penetrasi medan listrik vertikal dan gelombang EM ini ke ionosfer mengganggu konsentrasi elektron dan menyebabkan iregularitas (Pulinets et. al., 2003; Pulinets, 2004). Gangguan-gangguan ini muncul di zona gempa, yang radiusnya dinyatakan dengan rumus Dobrovolsky, 
$\rho=10^{0,43 \mathrm{M}} \mathrm{km}$ (Pulinets et. al., 2003; Pulinets dan Boyarchuk, 2004; Tsolis dan Xenos, 2009).

Penelitian lebih banyak dilakukan pada lapisan $\mathrm{F}$ ionosfer karena lapisan ini muncul pada siang dan malam hari. Berdasarkan studi kasus yang dilakukan oleh T. Xu, dkk. (2010), terjadi penurunan frekuensi kritis (foF2) pada lapisan F ionosfer dari median bulanannya 3 hari sebelum gempa Wenchuan, China pada tanggal 12 Mei 2008. Pada saat gangguan terjadi aktivitas geomagnet dan aktivitas matahari normal. Oleh karena itu gangguan pada lapisan $\mathrm{F}$ kemungkinan besar disebabkan oleh gempa bumi yang akan terjadi. Selain perubahan frekuensi kritis foF2 (naik atau turun dari median bulanannya) lapisan $\mathrm{F}$ ionosfer, ada juga gangguan berupa E-sporadis dan Spread F.

E-sporadis merupakan lapisan ionosfer yang muncul tiba-tiba dan dapat mengganggu komunikasi radio gelombang pendek. Sedangkan Spread $F$ merupakan penyebaran jejak Penyebaran jejak ini terjadi karena ketidakstabilan yang terjadi di bawah ketinggian lapisan F ionosfer (Ednofri, 2006). Menurut Muslim (2001) tingkat gangguan Spread $F$ ini sebanding dengan gangguan oleh aktivitas matahari. Pengamatan Spread $F$ dapat dilakukan tanpa membutuhkan waktu yang lama, karena dapat diamati langsung pada ionogram hasil rekaman ionosonda tanpa harus memisahkan parameter-parameter ionogram.

Model gravitasi-akustik atmosfer merupakan model paling populer untuk menjelaskan bahwa sebelum terjadinya gempa bumi gelombang gravitasi-akustik atmosfer dieksitasikan dari daerah persiapan gempa yang menjalar melalui atmosfer mencapai ketinggian ionosfer. Gangguan yang terjadi pada partikel netral oleh gelombang atmosfer menyebabkan gangguan pada ionosfer melalui tumbukan antara partikel-partikel netral dan terionisasi dari lapisan ionosfer (Gokhberg dan Shamilov, 2004).

Metode untuk mengamati lapisan ionosfer yang paling banyak digunakan adalah menggunakan ionosonda (Kaloka et al., 2010). Ionosonda adalah semacam radar aktif yang memancarkan dan sekaligus menerima gelombang elektromagnetik pada rentang frekuensi HF (3 - $30 \mathrm{MHz})$. Ionosonda memancarkan pulsa secara berurutan mulai dari frekuensi terendah hingga ke frekuensi tertinggi, kemudian merekam kembali pulsa yang dipantulkan oleh ionosfer dan mencatat selang waktunya. Dari informasi frekuensi dan selang waktu tersebut, ionosonda membuat plot frekuensi versus jarak dan menggambarkannya dalam ionogram.

Spread $F$ merupakan penyebaran gelombang radio di daerah lapisan $F$ akibat ketidakteraturan ionosfer di daerah tersebut. Waktu kejadian Spread $F$ yaitu setelah matahari terbenam hingga sebelum matahari terbit pagi hari (jam 18.00-07.00). Spread $F$ disebabkan oleh aktivitas di matahari, gangguan geomagnet dan gravitasi. Pada saat matahari maksimum akan terjadi flare yang lebih sering dan lebih kuat dibandingkan pada saat matahari minimum, sehingga gangguan medan magnet bumi pada matahari maksimum juga semakin besar. Apabila medan magnet bumi terganggu maka ionosfer juga akan terganggu (Muslim B, 2001). Menurut Ruhimat (2001) setelah terjadi gangguan geomagnet, secara kualitatif dapat dilihat adanya kelainan dari data ionosfer yaitu penurunan frekuensi kritis lapisan F2 dibandingkan dengan mediannya. Pengaruh tersebut terjadi antara satu sampai tiga jam setelah gangguan geomagnet. Sedangkan menurut Muslim (2010), penurunan gravitasi lokal dapat menyebabkan penurunan tekanan atmosfer lokal. Parameter dari aktivitas matahari yang lebih dekat korelasinya dengan kejadian Spread $F$ adalah bilangan sunspot. Bilangan sunspot merupakan banyaknya bintik hitam pada matahari akibat kuatnya medan magnet dipermukaan matahari. Hal ini 
menunjukkan adanya keterkaitan antara aktivitas geomagnet, aktivitas matahari, dan gravitasi terhadap ionosfer.

\section{DATA DAN METODE PENELITIAN}

\subsection{Data}

Data diperoleh dari ionogram hasil pengamatan menggunakan ionosonda FMCW di Koto Tabang dari tanggal 20 Februari sampai 20 Maret 2007. Kondisi ionosfer direkam setiap lima menit, mulai dari pukul 00:00 sampai 23:55 . Parameter yang diolah adalah iregularitas ionosfer yaitu terjadinya Spread F. Data bilangan sunspot diperoleh dari international Solar-Geophysical (SGD) dan data aktifitas geomagnet diperoleh dari World Data Center C-2 Kyoto University, Jepang.

\subsection{Metode Penelitian}

Pengolahan data dilakukan untuk mengetahui keterkaitan antara Spread $F$ ionosfer dengan kejadian gempa bumi Solok yang terjadi pada tanggal 6 Maret 2007. Langkahlangkah pengolahan data ionosfer yaitu sebagai berikut:

1. Melakukan scaling data frekuensi kritis lapisan F2 dengan rentang waktu waktu pengamatan dari tanggal 20 Februari sampai 20 Maret 2007.

2. Mengamati seluruh data ionogram hasil scaling frekuensi kritis lapisan F2 dan mencatat waktu kemunculan Spread F.

3. Memisahkan data Spread $F$ dengan data ionogram yang tidak mengalami gangguan.

4. Mengamati grafik bilangan sunspot matahari dan grafik aktivitas geomagnet pada waktu yang sama.

5. Membandingkan antara ketiga data tersebut untuk melihat apakah ada pengaruh dari aktivitas geomagnet dan bilangan sunspot matahari terhadap kemunculan Spread F.

6. Melakukan analisis terhadap keterkaitan antara kemunculan Spread $F$ yang tidak dipengaruhi oleh aktivitas geomagnet dan bilangan sunspot matahari dengan gempa bumi yang terjadi.

\section{HASIL DAN DISKUSI}

Dari data gempa Solok 6 Maret 2007, diperoleh radius zona persiapan gempa Solok adalah sebesar 564,94 km. Radius tersebut lebih besar daripada jarak antara pusat gempa dengan lokasi ionosonda di LAPAN SPD Kototabang. Dengan demikian, kondisi ionosfer yang tercatat menggunakan ionosonda tersebut dipastikan terpengaruh oleh aktivitas seismik sebelum gempa terjadi.

Untuk pengamatan data ionosfer dibagi menjadi tiga periode, pengamatan ionosfer periode pertama dilakukan dari tanggal 20 sampai dengan 26 Februari 2007. Pengamatan periode kedua dilakukan dari tanggal 27 Februari sampai dengan tanggal 5 Maret 2007, dan pengamatan ionosfer periode ketiga dilakukan dari tanggal sampai dengan 20 Maret 2007. Pengamatan ini lebih difokuskan pada waktu sebelum gempa khususnya malam hari supaya dapat diketahui korelasi Spread $F$ ionosfer dengan terjadinya gempa.

\subsection{Pengamatan Ionosfer Periode Pertama}

Gambar 1 menunjukkan fluktuasi frekuensi kritis lapisan F ionosfer (foF2) yang tidak terputus dan frekuensi kritis lapisan F ionosfer (foF2) yang maksimum terjadi pada siang hari, dan menurun pada saat menjelang pagi. Hal ini menunjukkan aktivitas lapisan $\mathrm{F}$ ionosfer pada kondisi normal. Siklus aktivitas ionosfer ini akan berulang setiap harinya. 
Pada hari yang sama, aktivitas geomagnet berada pada rentang -1 nTesla sampai dengan 10 nTesla seperti yang terlihat pada Gambar 2. Kondisi ini menunjukkan bahwa aktivitas geomagnet berada dalam keadaan normal karena fluktuasi aktivitas geomagnet memiliki amplitudo yang kecil. Adanya gangguan pada aktivitas geomagnet dapat diketahui dengan terdapatnya fluktuasi amplitudo aktivitas geomagnet yang menurun cukup drastis hingga mencapai ratusan nano Tesla (Ruhimat, 2001).

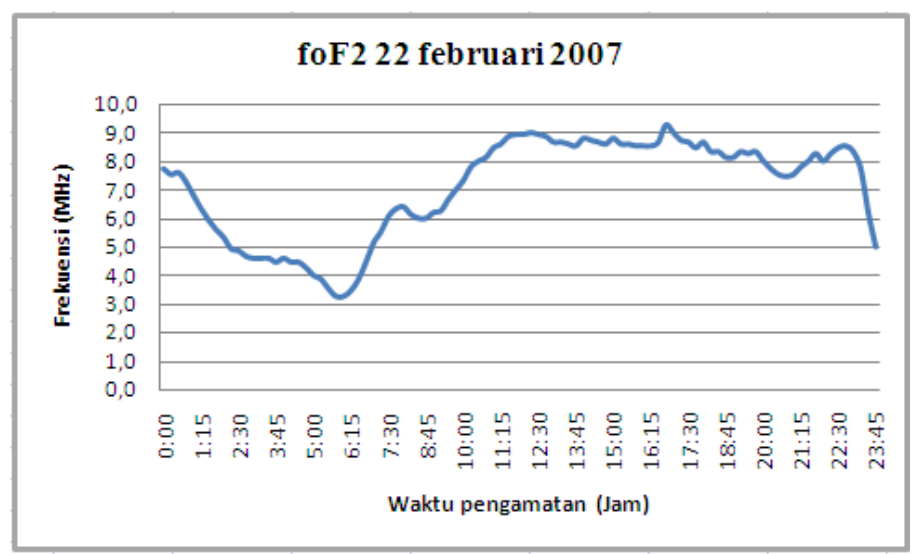

Gambar 1. Frekuensi Kritis Ionosfer tanggal 22 Februari 2007.

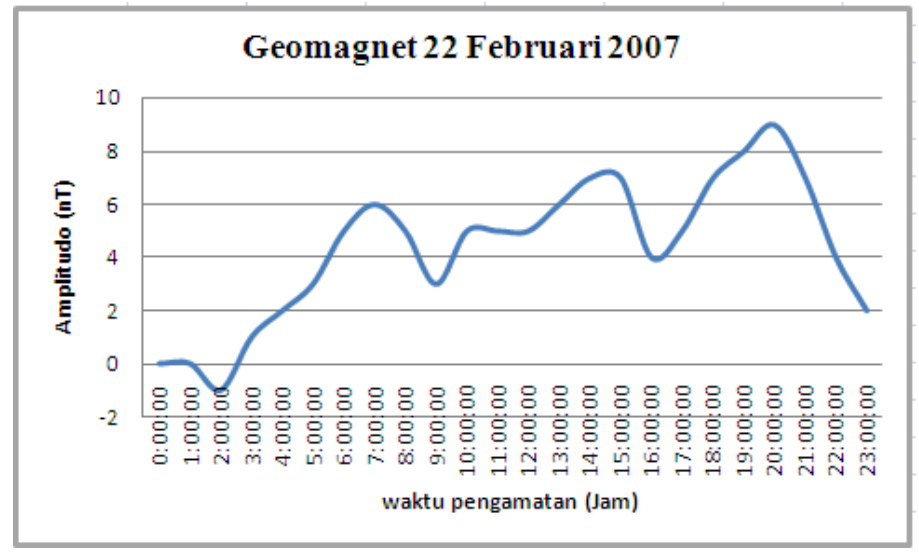

Gambar 2. Aktivitas geomagnet tanggal 22 Februari 2007.

Tanggal 23 Februari 2007 kondisi ionosfer menunjukkan frekuensi yang rendah pada pukul 00:00 sampai dengan pukul 06:15 yaitu lebih kecil dari $4 \mathrm{MHz}$ dan meningkat hingga $10 \mathrm{MHz}$ pada siang hari. Kondisi ini masih normal karena pola frekuensi kritisnya dapat diamati setiap waktu seperti Gambar 3. Fluktuasi geomagnet berada pada rentang -6 sampai 6 nT yang masih dalam keadaan normal seperti pada Gambar 4 


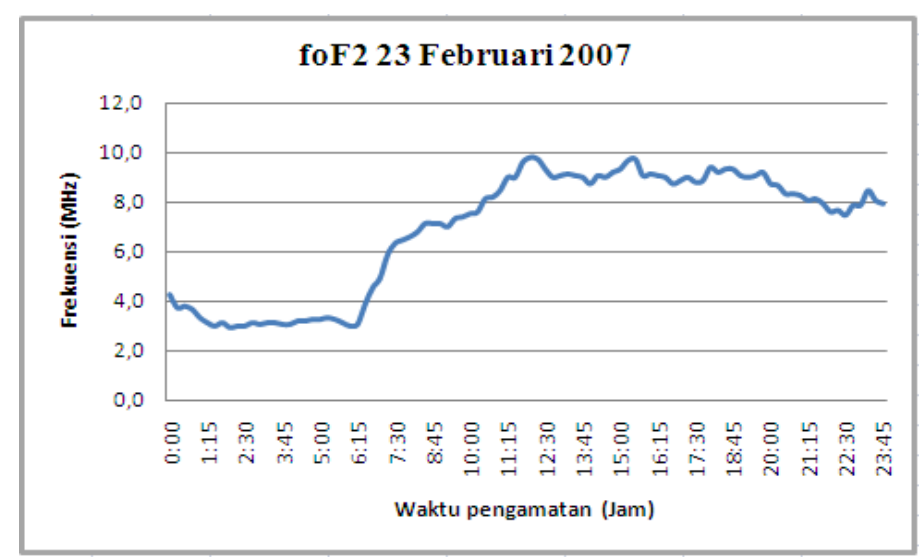

Gambar 3. Frekuensi kritis Ionosfer tanggal 23 Februari 2007.

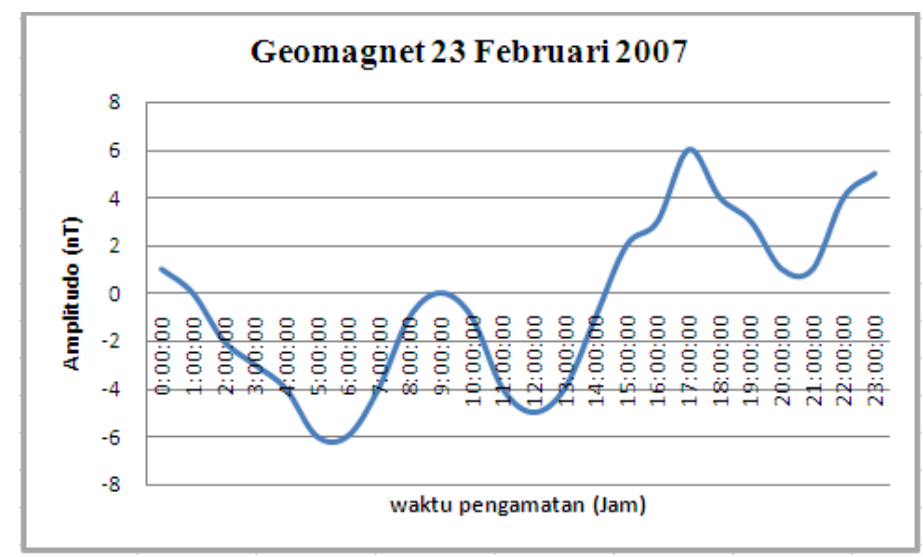

Gambar 4. Aktivitas Geomagnet tanggal 23 Februari 2007.

Pada 24 Februari 2007 kondisi lapisan F ionosfer tidak mengalami penyebaran jejak lapisan $\mathrm{F}$ ionosfer (Spread $F$ ) namun terdapat gangguan lapisan $\mathrm{E}$ (E-Sporadis) pada siang harinya yaitu pada pukul 05:00 dan frekuensi kritis lapisan F ionosfer (foF2) berada di luar batas frekuensi pengamatan sehingga tidak dapat diamati pada ionogram. Pukul 07:00 frekuensi kritis lapisan $\mathrm{F}$ ionosfer mulai meningkat seiring dengan meningkatnya panas yang dipancarkan oleh matahari, seperti yang terlihat pada Gambar 5. Hal ini karena pada siang hari panas matahari tinggi dan menurun saat menjelang sore. Pada hari yang sama aktivitas geomagnet berada pada rentang -4 sampai $4 \mathrm{nT}$, hal ini menunjukkan bahwa aktivitas geomagnet normal, seperti yang ditunjukkan pada Gambar 6 . 


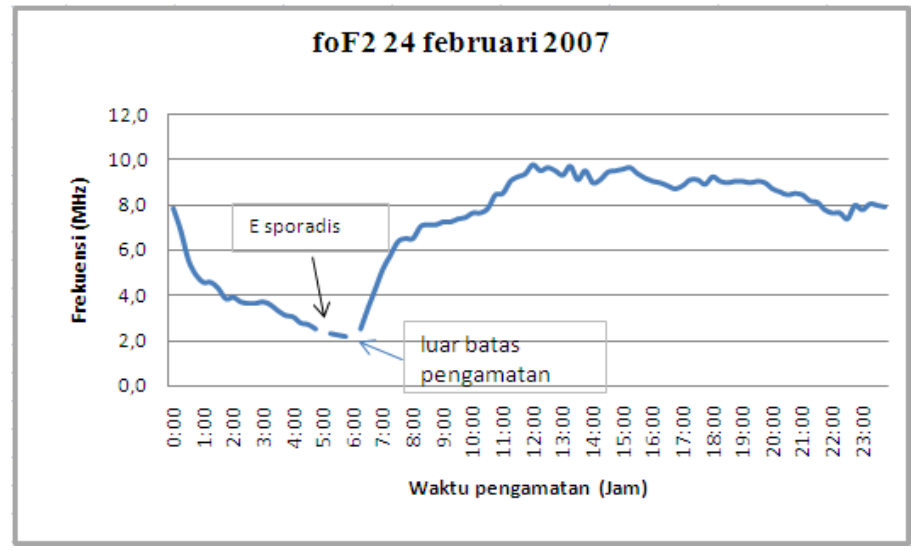

Gambar 5. Frekuensi kritis ionosfer tanggal 24 Februari 2007.

Dari hasil pengamatan untuk periode pertama dari data ionosfer yaitu tanggal 20 Februari sampai dengan 26 Februari 2007, terlihat bahwa lapisan F ionosfer normal seperti yang teramati pada tanggal 22, 23, 24 Februari 2007. Aktivitas geomagnet juga menunjukkan kondisi yang tenang. Hal ini terlihat dari amplitudo fluktuasi geomagnet yang bernilai kecil yaitu kurang dari $100 \mathrm{nT}$. Dapat disimpulkan bahwa lapisan F ionosfer tenang tanpa ada gangguan dari aktivitas geomagnet.

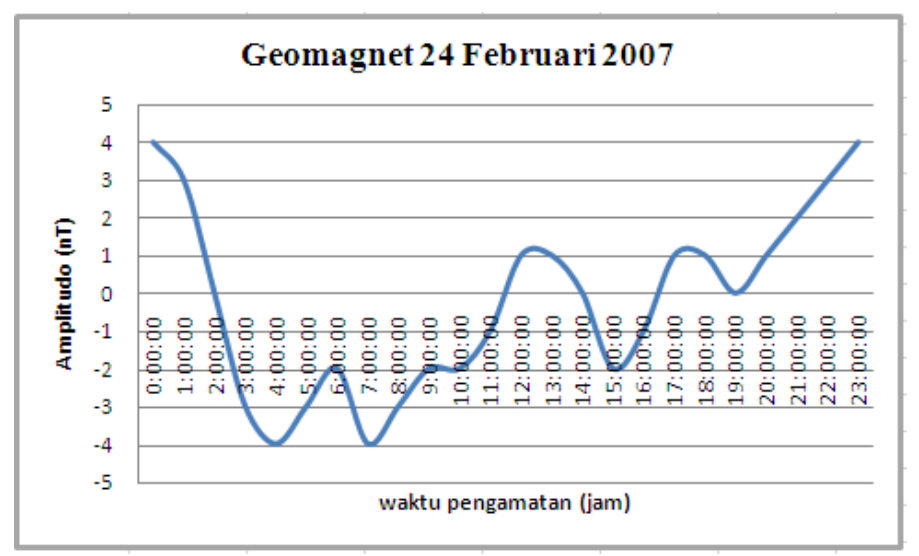

Gambar 6. Aktivitas geomagnet tanggal 24 Februari 2007.

\subsection{Pengamatan Ionosfer Periode Kedua}

Pengamatan data ionosfer untuk periode kedua ini dilakukan dari tanggal 27 Februari 2007 sampai dengan tanggal 6 Maret 2007. Tanggal 2 Maret 2007 frekuensi kritis lapisan $\mathrm{F}$ ionosfer terputus pada pukul 04:30 sampai 05:30 karena frekuensi kritis lapisan $\mathrm{F}$ ionosfer berada di luar batas frekuensi pengamatan. Hal ini menunjukkan bahwa frekuensi kritis lapisan F ionosfer rendah yaitu kecil dari 2 MHz. Pada pukul 05:45 sampai 06:00 teramati adanya kejadian E-Sporadis (ES) pada lapisan E yang menyebabkan gelombang yang dipantulkan ionosonda tidak dapat mencapai lapisan $\mathrm{F}$. Kemudian pukul 17:45-19:00 LT muncul E-Sporadis lagi dan berlanjut dengan kejadian Spread $F$ pada pukul 19:15-20:00. Setelah 45 menit, Spread $F$ terjadi lagi yaitu dari pukul 20:45-22:45 seperti ditunjukkan pada Gambar 7.

Gambar 8 menunjukkan adanya aktivitas geomagnet yang mengalami kenaikan fluktuasi pada jam 00:00 hingga puncaknya pada jam 09:00 dan pada akhir malam kembali terjadi 
penurunan aktivitas geomagnet yaitu mencapai -12 nTesla pada pukul 22:00. Pada kondisi ini masih tergolong normal karena aktivitas geomagnet memiliki amplitudo antara -2 nTesla sampai dengan -21 nTesla. Gangguan geomagnet dapat diketahui jika fluktuasi aktivitas geomagnet menurun cukup drastis hingga ratusan nT. Kemunculan Spread $F$ memiliki korelasi negatif terhadap aktivitas geomagnet yang artinya jika adanya gangguan aktivitas geomagnet maka tidak terjadi kemunculan Spread F (Ednofri, 2006).

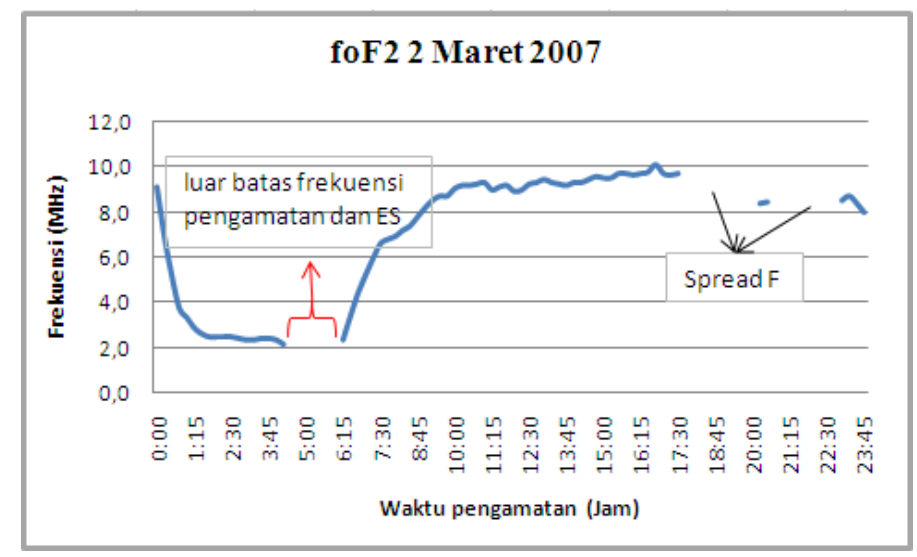

Gambar 7. Frekuensi kritis ionosfer tanggal 2 Maret 2007.

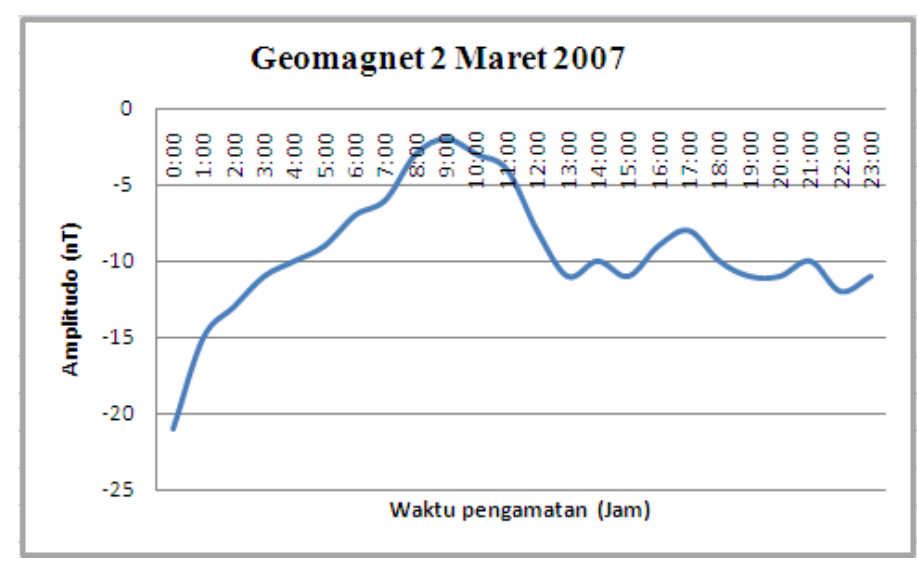

Gambar 8. Aktivitas geomagnet tanggal 2 Maret 2007.

Kondisi ionosfer pada tanggal 3 Maret 2007 menunjukkan penurunan frekuensi dari pukul 00:00 sampai dengan 02:30 karena menurunnya intensitas matahari. Pukul 03:00 sampai pukul 06:15 dan pada pukul 20:00 terdapat gangguan pada lapisan E yaitu E-Sporadis. Pada pukul 20:45 sampai dengan pukul 23:45 terdapat kemunculan Spread F seperti ditunjukkan pada Gambar 9. Aktivitas geomagnet berada pada rentang 2 sampai $-10 \mathrm{nT}$ yang menunjukkan kondisi geomagnet tenang walaupun terdapat peningkatan dan penurunan aktivitas geomagnet tersebut seperti terlihat pada Gambar 10. 


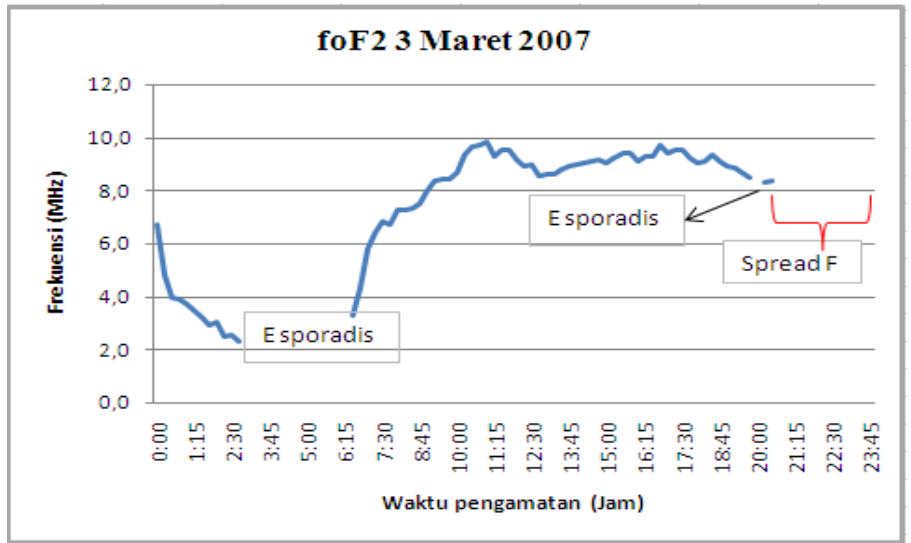

Gambar 9. Frekuensi kritis ionosfer tanggal 3 Maret 2007.

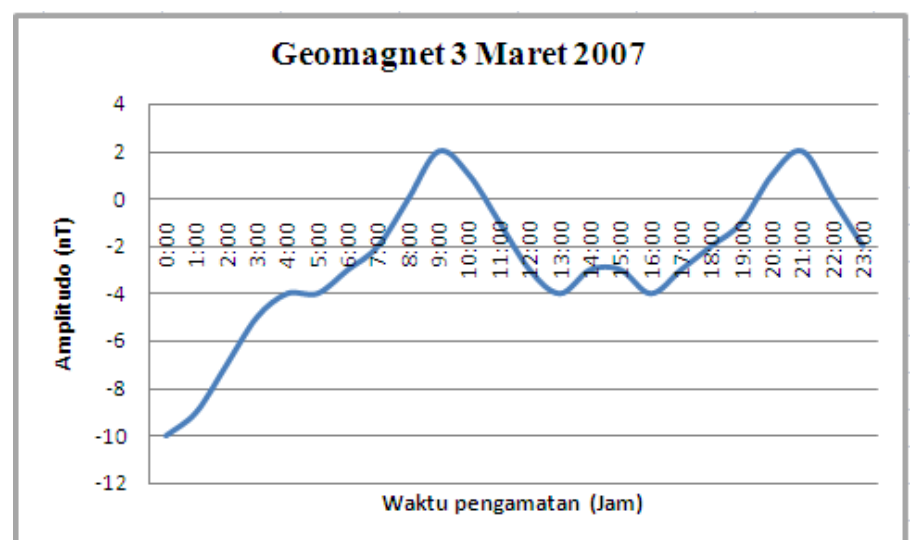

Gambar 10. Aktivitas geomagnet tanggal 3 Maret 2007.

Pada tanggal 5 Maret 2007 Spread $F$ terjadi pada akhir malam yaitu jam 02:00 sampai 03:00 seperti pada Gambar 11. Aktivitas geomagnet pada hari yang sama menunjukkan aktivitas yang normal seperti pada Gambar 12 .

Pengamatan untuk periode kedua yang dilakukan dari tanggal 27 Februari 2007 sampai dengan 6 Maret 2007, yaitu seminggu sebelum terjadinya gempa menunjukkan adanya kemunculan Spread $F$ pada lapisan F ionosfer. Kemunculan Spread $F$ ini tidak dipengaruhi oleh aktivitas geomagnet, karena dari pengamatan data geomagnet tidak ada gangguan pada geomagnet tersebut sehingga tidak mempengaruhi lapisan F ionosfer.

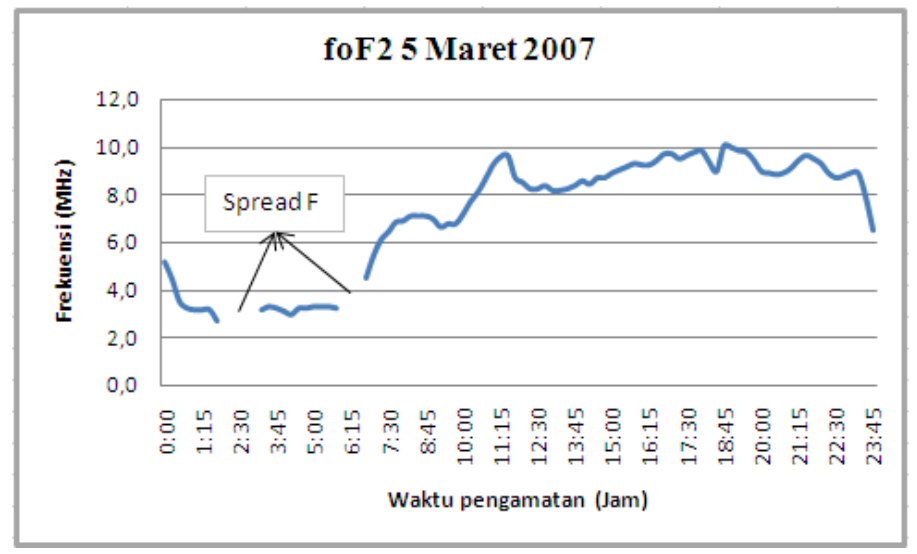

Gambar 11. Frekuensi kritis ionosfer tanggal 5 Maret 2007. 


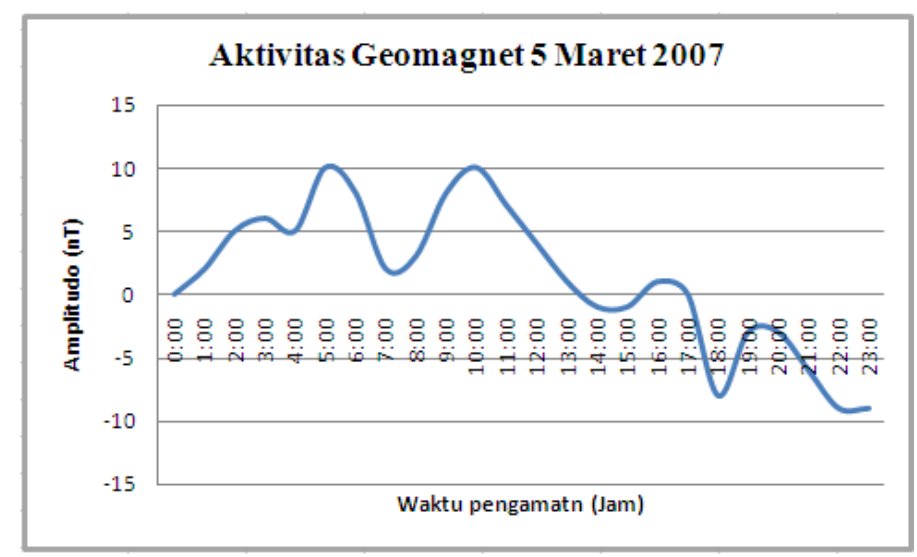

Gambar 12. Aktivitas geomagnet tanggal 5 Maret 2007.

\subsection{Pengamatan Ionosfer Periode Ketiga}

Pengamatan ini dilakukan dari tanggal 7 Maret 2007 sampai tanggal 20 Maret 2007. Gambar 13 menunjukkan kondisi ionosfer normal tanpa adanya gangguan yang menyebabkan frekuensi kritis lapisan F ionosfer (foF2) tidak teramati. Frekuensi kritis lapisan $\mathrm{F}$ ionosfer menurun pada malam hari hingga pagi dan meningkat pada siang hingga malam harinya. Aktivitas geomagnet memiliki amplitudo pada rentang 5 sampai dengan -25 nT yang artinya geomagnet dalam kondisi normal seperti ditunjukkan pada Gambar 14.

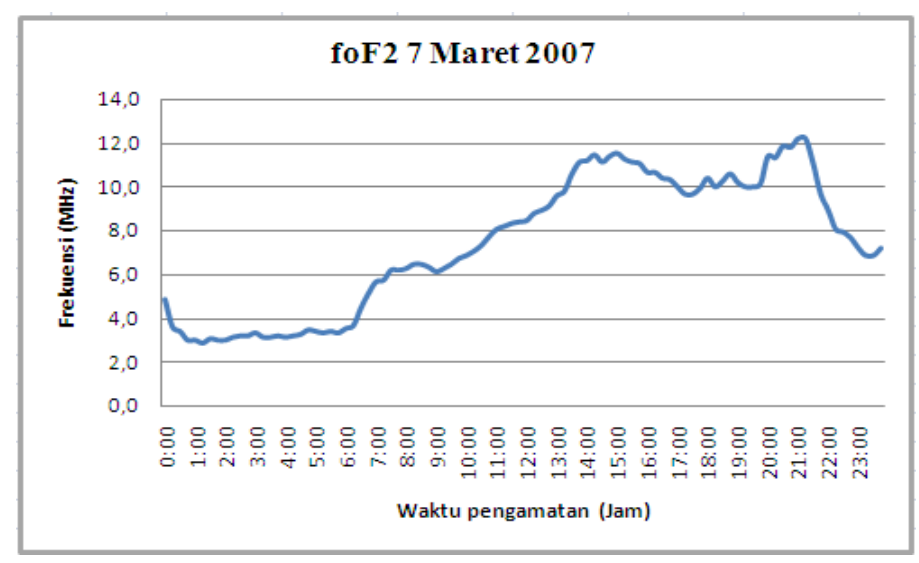

Gambar 13. Frekuensi kritis ionosfer tanggal 7 Maret 2007. 


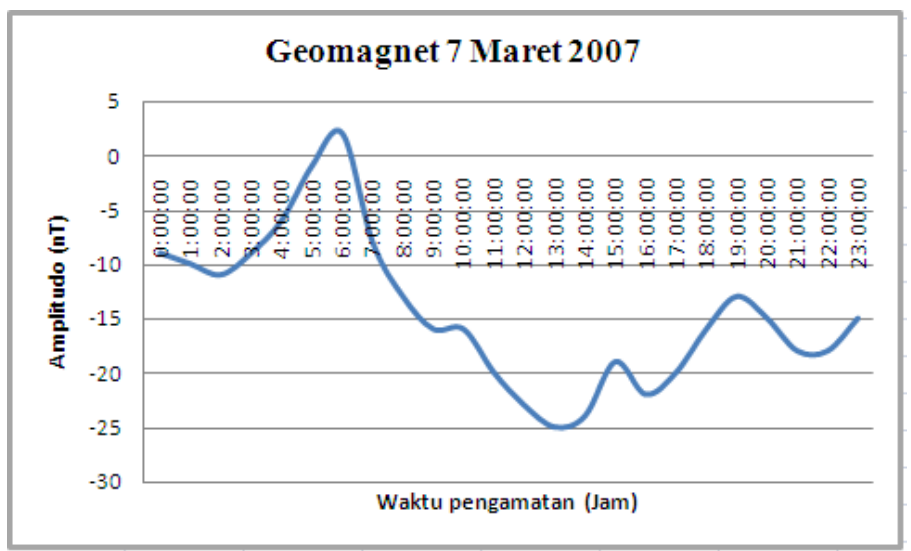

Gambar 14. Aktivitas geomagnet tanggal 7 Maret 2007.

Tanggal 8 maret 2007 kondisi ionosfer normal, ini terlihat dari fluktuasi frekuensi kritis lapisan $\mathrm{F}$ ionosfer (foF2) yang dapat diamati setiap waktu. Pada pagi hari frekuensi lapisan $\mathrm{F}$ minimum dan maksimum pada siang hari akibat aktivitas matahari yang meningkat, seperti terlihat pada Gambar 15. Sementara geomagnet berada pada rentang 13 sampai -22 nT, dimana amplitudonya bernilai kecil artinya kondisi geomagnet menunjukkan tidak adanya gangguan seperti yang terlihat pada Gambar 16.

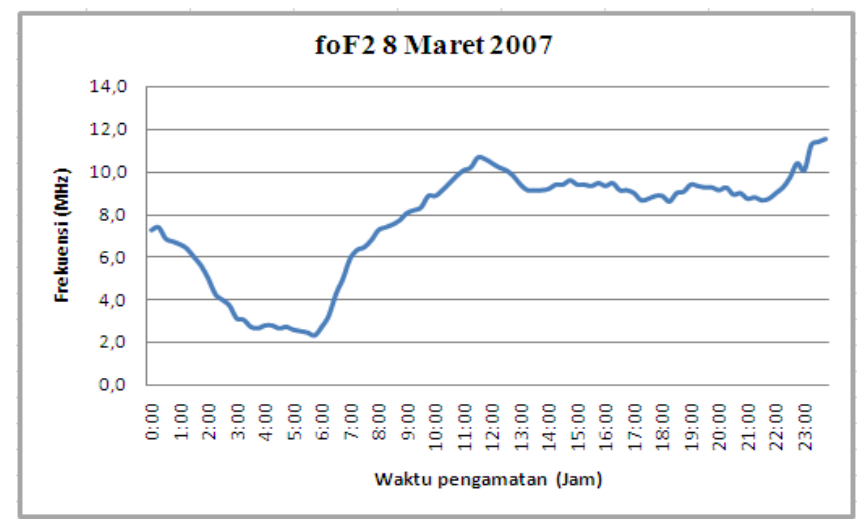

Gambar 15. Frekuensi kritis ionosfer tanggal 8 Maret 2007.

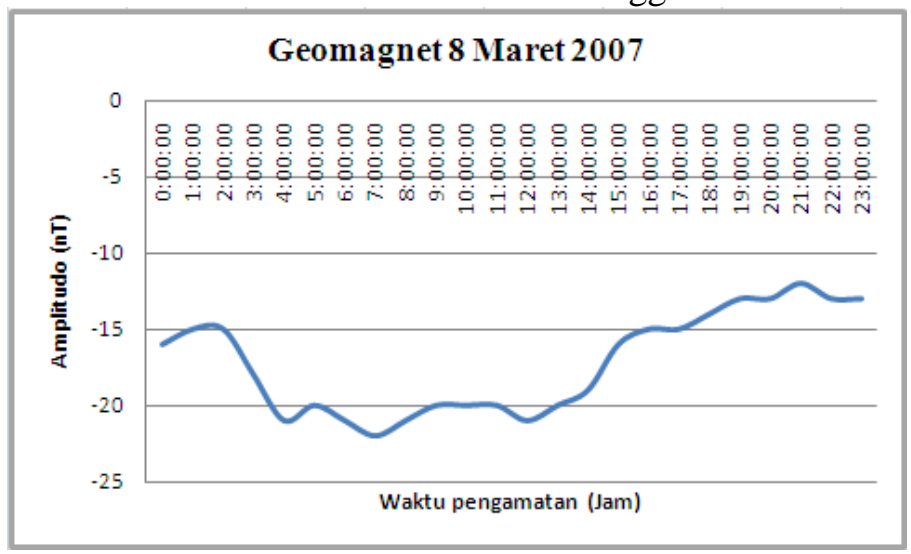

Gambar 16. Aktivitas geomagnet tanggal 8 Maret 2007. 
Kondisi frekuensi kritis lapisan $\mathrm{F}$ ionosfer mengalami penurunan mulai tengah malam sampai pagi hari, dan kembali meningkat pada siang harinya. Hal ini karena aktivitas matahari maksimum pada siang hari seperti ditunjukkan oleh Gambar 17. Aktivitas geomagnet tanggal 9 Maret 2007 menunjukkan kondisi yang tenang. Hal ini dapat dilihat dari rentang aktivitas geomagnet yang kecil yaitu -4 sampai $-12 \mathrm{nT}$ seperti ditunjukkan oleh Gambar 18.

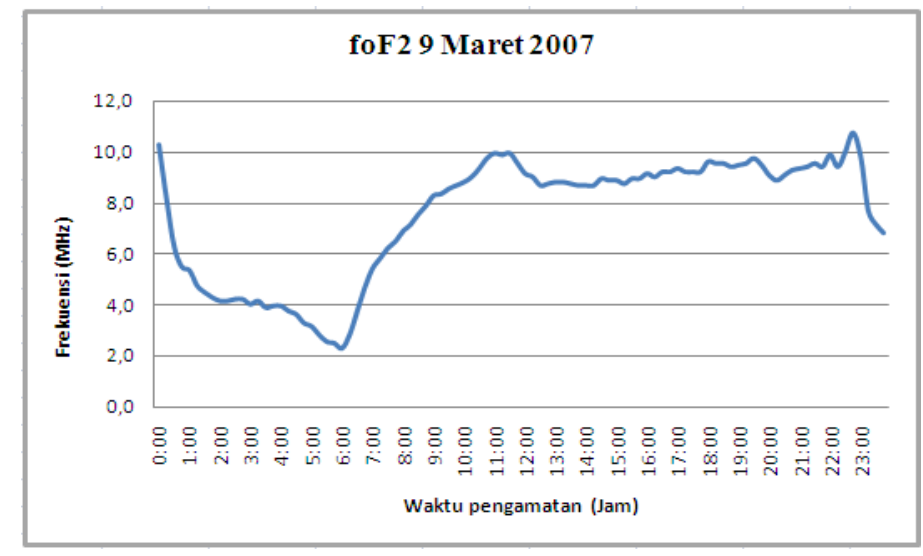

Gambar 17. Frekuensi kritis ionosfer tanggal 9 Maret 2007.

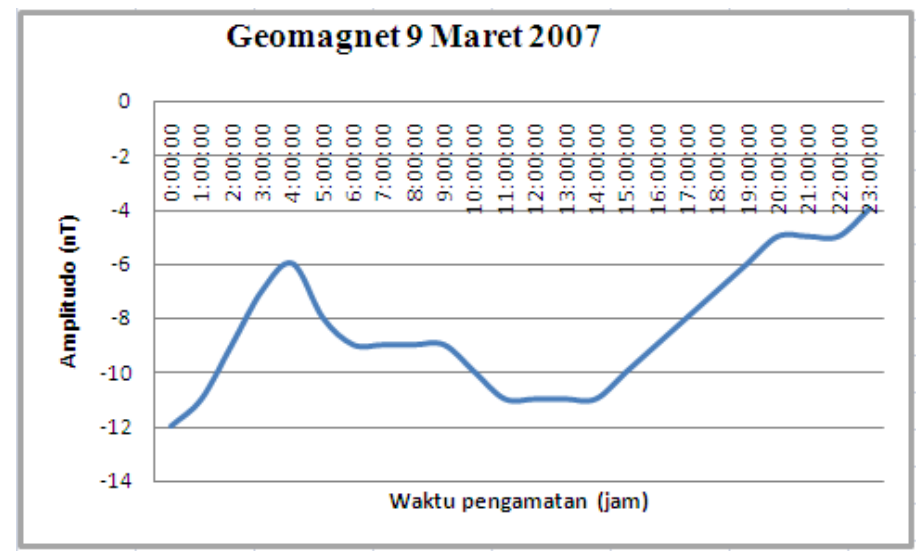

Gambar 18. Aktivitas geomagnet tanggal 9 Maret 2007.

Setelah dilakukan pengamatan data ionosfer sebelum gempa didapatkan gangguan pada lapisan E dan lapisan F, dimana sebagian besar kejadian Spread $F$ didahului dengan kemunculan E-Sporadis. Data ionosfer yang diamati setelah kejadian gempa 6 Maret 2007 yaitu mulai tanggal 7 sampai 20 Maret 2007. Setelah terjadinya gempa, kondisi frekuensi kritis lapisan $\mathrm{F}$ ionosfer kembali normal yang artinya tidak ada gangguan pada lapisan $\mathrm{F}$ ataupun lapisan E. Jelaslah bahwa pada pengamatan ionosfer periode pertama kondisi ionosfer menunjukkan keadaan yang normal, pada pengamatan ionosfer periode kedua didapat banyak munculnya Spread $F$ dan pada pengamatan ionosfer periode ketiga yaitu setelah gempa kondisi ionosfer kembali normal. Hal ini karena setelah gempa tidak ada lagi aktivitas patahan kerak bumi sehingga tidak ada gas dari batuan yang mempengaruhi ion-ion pada lapisan $\mathrm{F}$ ionosfer. 


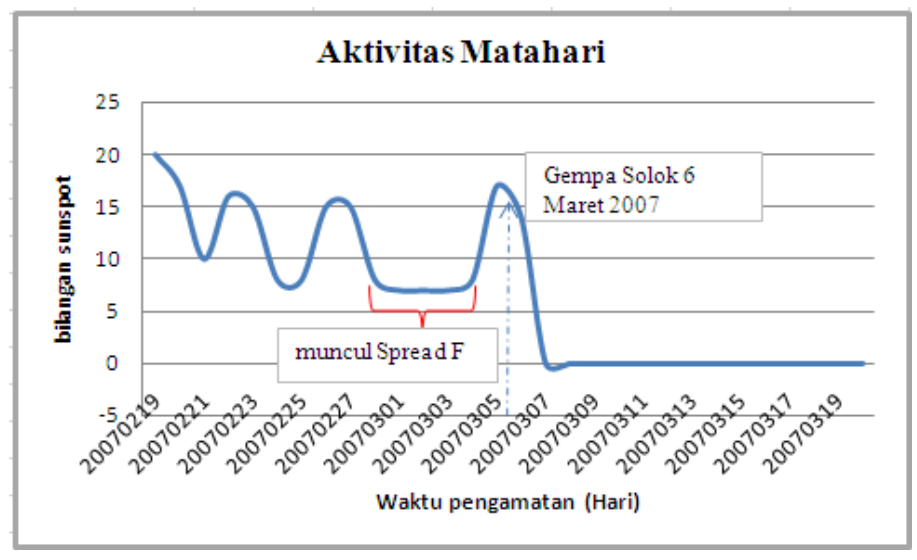

Gambar 19. Aktivitas matahari dengan Parameter bilangan sunspot.

Gambar 19 menunjukkan aktivitas matahari berdasarkan bilangan sunspotnya. Aktivitas matahari menurun mulai dari tanggal 19 sampai dengan 21 Februari 2007 yaitu dari bilangan sunspot 20 menjadi 10 dan meningkat lagi pada tanggal 22 Februari 2007, kondisi ini berulang sampai tanggal 27 Februari 2007. Pada tanggal 1 sampai dengan 3 Maret 2007 bilangan sunspotnya tetap yaitu bernilai 7, kemudian meningkat pada tanggal 5 Maret 2007 dengan bilangan sunspot 17 dan terjadi penurunan hingga bilangan sunspot menjadi nol pada tanggal 7 sampai dengan 20 Maret 2007. Bilangan sunspot merupakan banyaknya bintik hitam pada matahari yang dapat menimbulkan ledakan pada permukaan matahari. Bilangan sunspot memiliki korelasi yang positif dengan Spread F. Dalam jangka panjang dari tahun 1992 sampai 1995 aktivitas matahari tahunan memiliki hubungan yang cukup kuat terhadap Equatorial Spread $F$ atau ESF (Muslim, 2001). Jika bilangan sunspot besar maka frekuensi munculnya Spread $F$ akan besar pula.

Dari perbandingan hasil pengamatan antara data frekuensi kritis ionosfer, data geomagnet dan data aktivitas matahari selama periode pengamatan dari tanggal 20 Februari sampai tanggal 20 Maret 2007 terlihat bahwa kondisi ionosfer pada pengamatan periode pertama menunjukkan keadaan normal. Pada pengamatan periode kedua terjadi gangguan lapisan F ionosfer yang merupakan prekursor gempa bumi Solok 6 Maret 2007 yang ditandai dengan kemunculan Spread $F$ ionosfer. Hal ini diperkuat dengan data aktivitas geomagnet pada periode tersebut yang tidak menunjukkan adanya gangguan dan data paramter bilangan sunspotnya konstan sebesar 7. Kondisi ionosfer normal kembali pada periode pengamatan yang ketiga setalah terjadinya gempa Solok.

\section{KESIMPULAN}

Dari analisis data ionosfer tanggal 20 Februari sampai 20 Maret 2007 dengan menggunakan data ionosonda FMCW di stasiun Pengamat Dirgantara Lapan Kototabang terlihat adanya kemunculan Spread $F$ sebelum terjadinya gempa Solok 6 Maret 2007. Kemunculan Spread $F$ terjadi pada periode kedua pengamatan yaitu pada tanggal 2, 3 dan 5 Maret 2007. Pada periode ini aktivitas geomagnet dan aktivitas matahari teramati dalam kondisi normal. Kondisi ionosfer kembali normal setelah terjadinya gempa Solok. Dari hasil pengamatan tersebut diprediksi bahwa kemunculan Spread F tersebut merupakan prekusor Gempa Solok.

\section{UCAPAN TERIMA KASIH}


Penulis berterima kasih kepada pihak Lembaga Penerbangan dan Antariksa Nasional (LAPAN) yang telah memberikan ijin penggunaan data ionosonda FMCW dari LAPAN SPD Kototabang.

\section{DAFTAR PUSTAKA}

1. Ednofri, Suhartini, S. (2006). Spread F Di Atas Kototabang. LAPAN: Kototabang.

2. Gokhberg, M.B., Shalimov, S.L. (2004). Influence of earthquakes and explosionson the ionosphere. Moscow: Institute of Physics of the Earth of the Russian Academy of Sciences.

3. Kaloka, S., Jiyo, Suhartini, S., Perwitasari, S., Mardiani, A. S., Dear, V., et al. (2010). Lapisan ionosfer, prediksi frekuensi, dan teknis komunikasi radio (Jiyo, Ed.). Bandung: Pusat Pemanfaatan Sains Antariksa LAPAN.

4. Muslim, B. 2001. Pemodelan waktu linier aktivitas matahari dan prediksi siklus maksimumke-23. Warta LAPAN. Vol 3. Hal 1. Bandung.

5. Pulinets, S. A. (2004). Ionospheric Precursors of Earthquakes: Recent Advances in Theory and Practical Applications. TAO, 15(3), 413-435.

6. Pulinets, S. A., dan Boyarchuk, K. (2004). Ionospheric Precursor of Earthquakes. Berlin: Springer-Verlag.

7. Pulinets, S. A., Legen'ka, A. D., Gaivoronskaya, T. V., dan Depuev, V. K. (2003). Main Phenomenological Features of Ionospheric Precursors of Strong Earthquakes. Journal of Atmospheric and Solar-Terrestrial Physics, 65, 1337-1347.

8. Ruhimat, M. 2001. Dampak aktivitas geomagnet terhadap lapisan ionosfer. Warta LAPAN. Vol 3. Hal 15-17. Bandung

9. T. Xu, Y. Hu, J. Wu, Z.Wu, Y. Suo, and J. Feng. (2010). Giant disturbance in theionospheric F2 region prior to the M 8.0 Wenchuan earthquake on 12 May 2008. China: Xidian University.

10. Tsolis, G. S., dan Xenos, T. D. (2009). Seismo-ionospheric coupling correlation analysis of earthquakes in Greece, using empirical mode decomposition. Nonlin. Processes Geophys., 16, 123-130. 